\title{
COMPARATIVE STUDY OF EFFECTIVENESS OF COOPERATIVE LEARNING STRATEGY AND TRADITIONAL INSTRUCTIONAL METHOD IN THE PHYSICS CLASSROOM: A CASE OF CHIBOTE GIRLS SECONDARY SCHOOL, KITWE DISTRICT, ZAMBIA
}

\author{
Awoniyi Samuel Adebayo (Ph.D) \\ Associate Professor and Director Quality Assurance Solusi University, \\ Zimbabwe \\ Kamanga Judith \\ Chibote Girls Secondary School
}

\begin{abstract}
The purpose of the study was to compare the effectiveness of cooperative learning strategy and Traditional instructional method on pupils' academic achievement and their motivation to learn in the physics classroom at Chibote Girls Secondary School in Kitwe District of Zambia. The research was a Pre-test- post-test control group design. The population of the study consisted of 625 Grade Eleven pupils studying at Chibote Girls Secondary School in Kitwe District and the Five (5) teachers teaching physics subject at the school. A sample 60 pupils and two (2) teachers were used for the study. Simple random sampling was used to select the teacher to teach the Traditional instructional method (control) class and convenience sampling was used to select the teacher to teach the cooperative learning (experimental) class. Pre- and post- motivation survey questionnaire of the five point Likert scale of strongly agree to strongly disagree and pre- and post- tests were used for data collection. The motivational survey questionnaire was face and content validated while the tests were drawn from standardized past physics examination questions of the Examination Council of Zambia. The reliability for the pre- and post-motivational questionnaire survey was determined using the Cronbach's Alpha reliability method. The reliability coefficient of 0.334 and 0.901 was obtained for premotivational survey and post-motivational survey respectively. Factor analysis was carried out on the pre- motivational questionnaire survey and the communalities of the items on the pre- motivational survey ranged from 0.438 to 0.854 an indication that all the items on it were reliable. The two
\end{abstract}


motivational questionnaires were therefore, used for the research. The data collected were coded and analysed using the Statistical Packages for Social Sciences (SPSS). The one way Analysis of Variance (ANOVA) and Univariate Analysis of Variance and ANCOVA were employed. The study revealed that the use of Cooperative learning strategy do improve pupils' academic achievement as well as pupils' motivation to learn than the Traditional instructional method. Therefore, it is evident that Cooperative learning strategy is more effective in the teaching and learning of physics than Traditional instructional method.

Keywords: Effectiveness, Cooperative Learning Strategy, Traditional Instructional Method

\section{Introduction}

In Zambia, Science subject at senior level is divided into specific subject areas; physics and chemistry. These subjects are commonly taught by two different teachers who are specialists in those areas. Basically, Physics teaching encompasses the method of transmitting knowledge, skills and values on the scientific study of matter and energy to a learner (Muzumara, 2009). It deals with abstract concepts. Reveles, Cordova, and Kelly (2009) indicated that Physics dealt with abstract concepts and students found these concepts difficult to grasp.

It had been observed that, the pupils perform better in chemistry than in physics in some Secondary Schools. This is evidenced in the cumulative scores analyzed for the termly tests for Grade eleven in 2010 who later in 2011 wrote their Grade twelve O level Examinations in two Secondary schools in Kitwe District of Zambia. The overall performance for Secondary school A and B in Grade Twelve O level National Examinations was below 50 percent $(44.1 \%$ and $47.5 \%$ respectively) in Science Subject (ECZ, Examination Analysis, 2011).

The difficulties of many pupils with physics science subject could be traced back to the way they were introduced to this area of science course in primary school and now it had been refueled by the way the subject is taught at secondary level which always depends on the foundation laid by teachers at the lower level of education. In many countries, there is a decline in the number of students wishing to continue with physics (Woolnough, 1994). A number of factors have been identified by previous researchers as contributing to this decline.

Smithers (2010) noted that the study of physics in schools and universities was spiraling into decline as many teenagers believe it was too difficult. Sillitto and MacKinnon (2011) noted that physics had an image of being both 'difficult' and 'boring'. They further observed that the major 
reasons for students finding physics uninteresting are that it is seen as difficult and irrelevant. Thus, this calls for strengthening of teaching science subjects by using different methods which will activate motivational levels of pupils and thereby enhance quality performance. Bello (2011) stated that it is crucial for teachers to use the best effective teaching method, which could enhance academic achievement of students. To avert this problem, the mode of dissemination of Physics to the students' need be looked into so as to help the learners. Science (Physics) teachers have a unique opportunity to use cooperative learning strategies he added.

If learners are made to see science as a means of enriching personal life and improving national economy through making the surroundings more interesting and comprehensible, then there must be a change in the way science is taught in schools and this will also require a change in the teachers' perception of the context and method in which they teach. A paradigm shift from traditional instructional methods to learner centered approaches is essential. Cooperative learning has been proposed as one instructional strategy congruous with the paradigm shift. Cooperative learning is an approach to organizing classroom activities into academic and social learning experiences. It enhances motivation to learn in the classroom.

Researches such as those of Heller, Keith, and Anderson (1992); Johnson and Johnson (1992); Kagan (1990) and Chiu (2008) has shown that students who work in cooperative groups do better in tests, especially with regard to reasoning and critical thinking skills than those that do not and that they tended to perform better. At the national level, the Zambian Government has brought in different interventions to curb the problem of poor performance in science subjects through Strengthening Teaching Performance-UP (STEP-UP) for Zambia and Japanese International Coordinating Agency (JICA).

This initiative was implemented by the Ministry of Education, Science, Vocational Training and Early Education (MOESVTEE) through the School Based- Continuing Professional Development (SB-CPD) through School Programme In-Service for the Term (SPRINT) System. Cooperative learning was one teaching method encouraged under the program, but its effectiveness in improving learners' performance in science classroom has rarely been studied.

Kose, Sahin, Ergu and Gezer (2010) stated that there was ample evidence that cooperative learning strategies are instructionally effective in grades $2-9$, but relatively few studies examine grades $10-12$. This fact necessitated the desire for the researchers to compare the effectiveness of cooperative learning strategy with the Traditional Instructional Method on pupils' academic achievement and their motivation to learn in the physics 
classroom at Chibote Girls Secondary School in Kitwe District, Copperbelt Province of Zambia.

\section{Statement of the Problem}

The performance of pupils in science subjects in Kitwe District has been declining for the past five years. The pass rate for one of the secondary Schools dropped from $81.8 \%$ to $44.1 \%$ between 2007 and 2011 despite the fact that the school has adequate resources for teaching and learning of Science subjects as well as qualified teachers to teach. These notwithstanding, pupils still expressed negative comments about sciences especially physics as being tough and boring. One issue that could be raised was the effectiveness of the Traditional instructional method of teaching used in physics. Soliven (2003) studied the teaching styles of high school physics teachers, and found out that Physics teachers used different teaching styles and teachers who gave students group work cooperatively get a better result.

Furthermore, Zemke, Elger and Beller (2004) found that students overwhelmingly indicated that the use of effective events in Cooperative learning groups enabled them to more easily master difficult materials. This was a clear indication that the way the subject was taught needed to be looked into. This study therefore compared the effectiveness of Cooperative Learning Strategy and Traditional Instructional Method on academic achievement in the physics classroom as well as students' motivation to learn.

\section{Research Questions}

The researchers sought answers to the following questions:

1. Is there any significant difference in the academic achievement of pupils taught using Cooperative Learning strategies(experimental group) and those taught using Traditional instructional method(control group) before and after controlling for pre-test?

2. Is there any significant difference in the motivational levels of the experimental group and the control group in the physics classroom before and after controlling for pre-motivational survey?

\section{Research hypotheses} tested:

Based on the research questions, the following hypotheses were

Ho 1: There is no significant difference in academic achievement of pupils taught using Cooperative learning Strategies (experimental group) and pupils taught using the Traditional instructional method (control group) in the physics classroom before and after controlling for pre-test. 
Ho 2: There is no significant difference in the motivational levels of the Experimental group and the control group before and after controlling for pre-motivational survey.

\section{Research Methodology}

The purpose of the study was to compare the effectiveness of cooperative learning strategy and Traditional instructional method on pupils' academic achievement and their motivation to learn in the physics classroom at Chibote Girls Secondary School in Kitwe District of Zambia. The research was a Pre-test- post-test control group design. The population of the study consisted of 625 Grade Eleven pupils studying at Chibote Girls Secondary School in Kitwe District and the Five (5) teachers teaching physics subject at the school. A sample 60 pupils and two (2) teachers were used for the study. Two classes of Physics were randomly selected for the study. Simple random sampling was used to select the teacher to teach the Traditional instructional method (control) class and convenience sampling was used to select the teacher with experience in cooperative learning strategy to teach the cooperative learning (experimental) class. Pre- and post- motivation survey questionnaire of the five point Likert scale of strongly agree to strongly disagree and pre- and post- tests were used for data collection.

The motivational survey questionnaire was face and content validated while the tests were drawn from standardized past physics examination questions of the Examination Council of Zambia. The items selected for the pre and posttest were based on the learning objectives on topics on Current Electricity and D.C. Circuits. The reliability for the pre- and postmotivational questionnaire survey was determined using the Cronbach's Alpha reliability method. The reliability coefficient of 0.334 and 0.901 was obtained for pre-motivational survey and post-motivational survey respectively. Factor analysis was carried out on the pre- motivational questionnaire survey and the communalities of the items on the premotivational survey ranged from 0.438 to 0.854 an indication that all the items on it were reliable. The two motivational questionnaires were therefore, used for the research.

The data collected were coded and analysed using the Statistical Packages for Social Sciences (SPSS). The one way Analysis of Variance (ANOVA) and Univariate Analysis of Variance and ANCOVA were employed. The study revealed that the use of Cooperative learning strategy do improve pupils' academic achievement as well as pupils' motivation to learn than the Traditional instructional method. Therefore, it is evident that Cooperative learning strategy is more effective in the teaching and learning of physics than Traditional instructional method. 


\section{Results and Discussions}

The results of the analysis are discussed in succession in line with the research questions and research hypotheses.

Research Question One: Is there any significant difference in the academic achievement of pupils taught using Cooperative learning strategies (Experimental group) and those taught using Traditional Instructional method ( Control group) before and after controlling for pre-test?

Table 1: Mean Achievement Scores of Post-test of the Experimental group and control group.

\begin{tabular}{|c|c|c|}
\hline Groups & Mean & Std. Deviation \\
\hline Control Group & 8.5667 & 5.19737 \\
\hline Experimental Group & 17.0667 & 7.57006 \\
\hline
\end{tabular}

Table 1 above shows the mean achievement scores of post-test for the Experimental group and Control group. The Experimental group outperformed their control group counterparts with a mean score of 17.0667 compared to a mean score of 8.5667. This is a clear indication that the Experimental Group taught using Cooperative learning strategies performed better than the control group taught using Traditional instructional method in the physics tests.

The mean score of 17.0667 for the Experimental group indicated a Pass Grade whereas the mean score of 8.5667 for the control group indicated a Fail Grade. This study is in line with Kose, Sahin, Ergu \& Geze (2010) that Cooperative Learning promote student's learning academic achievement, in the same vein, Fui \& Hong (2008) revealed that the Cooperative learning group outperformed the traditional instructional method group.

The study further revealed that in general the performance of the two groups were below average. This is in line with the statement from the Zambia's policy document 'Educating our Future' Ministry of Education (1996) which outlined that on average, less than two-thirds of the candidates obtain a full pass in school certificate each year in science subjects. This explained the distressing picture of poor performance in science subjects which includes physics as a core science subject. The standard deviation for the Experimental group of 7.57006 and that of the control group of 5.19737 were found to be high an indication that the groups were heterogeneous across in the test scores.

Table 2 shows the one way Analysis of Variance between academic achievement of pupils taught using Cooperative Learning Strategies (Experimental group) and those taught using Traditional Instructional method (control Group). The F- value of 25.706 was found to be significant 
(.000), an indication that there exists significant difference in the performance of the two groups. This is clear evidence that Cooperative learning strategy was more effective than the Traditional Instructional method.

\section{Table 2: One way Analysis of Variance between academic Achievement} of Experimental group and Control group

\begin{tabular}{|c|c|c|c|c|c|}
\multicolumn{1}{c|}{ ANOVA } & & \\
\cline { 2 - 6 } \multicolumn{1}{c|}{ Post-test } & & & & Sig. \\
\hline & Sum of Squares & Df & Mean Square & $\boldsymbol{F}$ & .000 \\
Between & 1083.750 & 1 & 1083.750 & 25.706 & \\
Groups & 2445.233 & 58 & 42.159 & & \\
Within Groups & 3528.983 & 59 & & & \\
Total & 353 & & & \\
\hline
\end{tabular}

This study is in line with various research reports stating that Cooperative learning was more effective than Traditional method of instruction(Johnson \& Johnson, 1995; Kagan,1994; Fui \& Hong, 2008; Tsay \& Brady, 2010; and Hamzah \& MdZain, 2010).

Table 3 shows the Analysis of covariance (ANCOVA) on the academic achievement of the Experimental group and the Control group. The F-value changes from 25.706 to 36.823 an indication that the pre-test resulted in slight improvement in the post test achievement but the difference in achievement between the experimental and the control group still significant. The pre-test enhanced the performance of pupils.

Table 3: Analysis of Covariance (ANCOVA)

Post-test

\begin{tabular}{|c|c|c|c|c|c|c|}
\hline Source & $\begin{array}{c}\text { Type III Sum } \\
\text { of Squares }\end{array}$ & Df & $\begin{array}{c}\text { Mean } \\
\text { Square }\end{array}$ & F & Sig. & $\begin{array}{c}\text { Partial Eta } \\
\text { Squared }\end{array}$ \\
\hline $\begin{array}{c}\text { Corrected } \\
\text { Model }\end{array}$ & $1803.622^{\mathrm{a}}$ & 2 & 901.811 & 29.793 & .000 & .511 \\
Intercept & 1162.229 & 1 & 1162.229 & 38.396 & .000 & .402 \\
pretest & 719.872 & 1 & 719.872 & 23.782 & .000 & .294 \\
class & 1114.616 & 1 & 1114.616 & 36.823 & .000 & .392 \\
Error & 1725.361 & 57 & 30.269 & & & \\
Total & 13385.000 & 60 & & & & \\
Corrected & 3528.983 & 59 & & & & \\
Total & 59 & & & & \\
\hline
\end{tabular}

a. R Squared $=.511$ (Adjusted R Squared $=.494)$ 
Based on the above findings, the Null hypothesis $\left(\mathrm{Ho}_{1}\right)$ which stated that there is no significant difference in the academic achievement of the Experimental and control group was rejected at 0.05 level of significance and the alternative hypothesis accepted. Significant differences therefore existed between the pupils taught via cooperative learning strategies and their traditional instructional method counterparts.

This agreed with Slavin (1995) who reported that overall, students in cooperative learning groups scored about one-fourth of the standard deviation higher on achievement test than did students taught conventionally (traditionally) and Johnson, Johnson \& Smith (1995) also revealed that the Cooperative learning groups had about two-thirds of a standard deviation higher in test scores than students in competitive or individualistic situations in traditional methods of instruction.

Research Question Two: Is there any significant difference in the Motivational level of the Cooperative Learning strategy group (Experimental group) and Traditional instructional method group (control group) before and after controlling for pre-motivation survey?

Table 4.4: The Mean Scores on Pupils' Motivational Level for Experimental Group and Control Group

\begin{tabular}{|c|c|c|}
\hline Groups & Mean & Std. Deviation \\
\hline Control Group & 2.3491 & .51688 \\
\hline Experimental Group & 4.4095 & .46399 \\
\hline
\end{tabular}

Table 4 above shows the mean scores of the pupils' motivational level to learn in the physics classroom between the Experimental group and the Control group. The table revealed that the Experimental group scored a mean of 4.4095 indicating that they were highly motivated whereas the control group scored a mean of 2.3491, which indicated that they were fairly motivated. This is a clear indication that Cooperative learning strategies increase the pupils' motivational levels to learn in the physics classroom than the Traditional instructional method.

This finding is in agreement with Peterson \& Miller (2009) who compared the experiences of students during cooperative learning and largegroup instruction (Traditional method) and found that the most consistent result of this study related to student motivation, all aspects of which were positive during cooperative learning. The low standard deviations for both groups indicated that they were homogenous in their motivational levels. 
Table 5: One Way Analysis Of Variance between Pupils' motivational Levels for Experimental Group and Control Group

\begin{tabular}{|c|c|c|c|c|c|}
\hline & Sum of Squares & df & Mean Square & F & Sig. \\
\hline Between & 61.553 & 1 & 61.553 & 255.167 & .000 \\
Groups & 13.509 & 56 & .241 & & \\
Within Groups & 75.061 & 57 & & & \\
Total &
\end{tabular}

Table 5 above shows the one way Analysis of variance (ANOVA) between the two groups in their post- motivational scores. The F-value of 255.167 was found to be significant, an indication that there exist a significant difference in the motivational levels of the two groups to learning physics. This is clear evidence that Cooperative learning strategies is more effective in increasing motivation to learn.

This study is in agreement with some researches in which Cooperative learning had been found to increase attendance, time on task, enjoyment of school and classes, motivation, and independence (Augustine, Gruber \& Hanson: 1990; Good, Reys, Grouws \& Mulryan, 1990; and Wood, 1987)

Table 6 below shows the Analysis of Covariance of Pre-motivation survey on the Pupils' motivational level to learn in the physics classroom for the Experimental group and the Control group. F- Value reduced from 255.167 to 249.475 but the differences in the motivational level of the two groups were found to be significant.

Table 4.6: Analysis of Covariance (ANCOVA)

Post Motivation Survey Average

\begin{tabular}{|c|c|c|c|c|c|c|}
\hline Source & $\begin{array}{c}\text { Type III Sum of } \\
\text { Squares }\end{array}$ & Df & Mean Square & F & Sig. & $\begin{array}{c}\text { Partial Eta } \\
\text { Squared }\end{array}$ \\
\hline Corrected Model & $61.573^{\mathrm{a}}$ & 2 & 30.787 & 125.538 & .000 & .820 \\
Intercept & 32.670 & 1 & 32.670 & 133.217 & .000 & .708 \\
Pre-motivation & .021 & 1 & .021 & .084 & .774 & .002 \\
Class & 61.181 & 1 & 61.181 & 249.475 & .000 & .819 \\
Error & 13.488 & 55 & .245 & & & \\
Total & 737.406 & 58 & & & & \\
Corrected Total & 75.061 & 57 & & & & \\
\hline
\end{tabular}

a. R Squared $=.820($ Adjusted R Squared $=\mathbf{. 8 1 4})$

Based on the above findings, the Null hypothesis which stated that there is no significant difference in the motivational levels of the Experimental group and the Control group was rejected at 0.05 level of significance. There is therefore, a significant difference in the pupils' 
motivational levels to learn in the physics classroom based on instructional strategies.

This finding is in line with that of Zemke, Elger \& Beller (2004) who found that students overwhelmingly indicated that the use of effective events enabled them to more easily master different material in cooperative learning group. He further stated that those students who worked in smaller groups in cooperative learning strategy were better motivated to learn physics; this might be as a result of better accessibility to the teacher during teaching and learning process than in the Traditional method class.

\section{Findings}

Following are the findings of the research:

1. The study revealed that the Cooperative learning strategy class (Experimental group) outperformed the Traditional instructional method class (control group) in the physics test and the difference in their academic achievement was found to be significant before and after controlling pre-test. However, the performance for both groups was generally below average.

2. The mean scores on pupils' motivational levels to learn revealed that the Experimental group was highly motivated whereas the Control group was only fairly motivated and their motivational levels to learn was significantly different before and after controlling pre-motivational survey.

3. This study revealed that Cooperative learning strategy is more effective than traditional instructional method.

\section{Conclusion}

It is evident that the use of Cooperative learning strategy does increase pupils' academic achievement as well as pupils' motivation to learn than Traditional instructional method. Therefore, Cooperative learning strategy is more effective in the physics classroom than in the Traditional instructional method. It is therefore recommended that cooperative learning method be adopted at all levels of education because of its emphasis on social interaction among the pupils in the classroom and most especially because of its impact on improved academic performance.

\section{References:}

Augustine, D.K., Gruber, K. D., \& Hanson, L. R. (1989-1990). Cooperation works! Educational Leadership, 47, 4-7.

Bello, T.O. (2011) Effect of Group Instructional Strategy on the Students' performance in Selected Physics Concepts.” The African Symposium: An 
Online Journal of the African Educational Research Network".11( 1),323-342.

Chiu, M. M. (2008).Flowing Towards Correct contribution during Groups' Mathematics Problems Solving: A Statistical Discourse Analysis. Journal of the Learning Sciences.17 (3), 415-463

E.C.Z, (2011) Examination Analysis O level Grade Twelve Examinations. Lusaka: ECZ

E.C.Z ,past Examinations Grade Twelve and GCE Questions From 2000 to 2012

Fui, F.H. \& Hong, K.B. (2008) Cooperative Learning: Exploring its Effectiveness in physics Classroom. Asia-pacific Forum on Science learning and Teaching.8 (2), 7

Good, T. L., Reys, B. J., Grouws, D. A., \& Mulryan, C. M.(1989-1990). Using Work groups in Mathematics instruction. Educational leadership. 47, 56-60.

Hamzah, M.S. and Md Zain, A.N. (2010) The Effect of Cooperative Learning with DSLM on Conceptual understanding and scientific reasoning among form four physics Students with Different Motivation Levels. "Bulgarian Journal of Science Education Policy (BJSEP)".4(2), 275-310

Heller, P. ,Keith, R. \& Anderson, R. (2008) Teaching Problem Solving Through Cooperative Grouping Part 1: Group Verses Individual Problem Solving. American J. Physics Teachers. 60,627-636.

Johnson, D. W. \& Johnson, R. T. (1993). Implementing cooperative learning. Education Digest.58 (8), 62.

Johnson, D., \& Johnson. (1995) Learning together and alone, cooperative, competitive and individualistic learning. Needham Heights, MA: PrenticeHall

Kagan, S. (1990). The Structural Approach to Cooperative Learning. Educational Leadership. 47(4), 12-15.

Kagan, S. (1994). Cooperative Learning. Educational Leadership: ProQuest Education Journals. 47(4), 52.

Kose, S., Sahin, A., Ergu, A., \& Gezer, K. (2010). The effects of cooperative learning experience on eight grade students' achievement and attitude toward science. Education. 131 (1), 169-180.

Ministry of Education (MoE) (1996) Educating our Future: National Policy on Education. Lusaka: Government Printers.

Muzumala, P.M.(2009) Becoming an Effective Science Teacher. Lusaka: National In-service Teachers' college.

Peterson, S. E. \& Miller, J. A. (2009). Comparing the Quality of Students' Experiences during Cooperative Learning and Large-Group Instruction. The Journal of Educational Research, 97(3), 123. 
Reveles, J. M., Cordova, R., Kelly, G. J. (2009). Science Literacy and Academic Identity Formulation. Journal of Research in Science Teaching, 41(10), 1111-1144

Sillitto, R., \& MacKinnon, L.M. (2011). Going SPLAT!: Building a multimedia educational resource for physics learners. Physics Education, 35 (5), 325-331

Slavin, R.E. (1995) Cooperative Learning. New Jersey: Prentice-Hall.

Smithers, R. (2010). Physics in downward spiral as pupils think it is too difficult. UK: The Guardian.

Step-up Zambia (2013)" STEPS Baseline Report Format 2".Kitwe: Copperbelt Stakeholder Workshop Keynote Presentation.

Tsay, M., \& Brady, M. (2010). A case study of cooperative learning and communication pedagogy: Does working in teams make a difference? Journal of the Scholarship of Teaching and Learning. 10(2), 78 - 89.

Woolnough, B.E. (1994) Why Students Choose Physics, or Reject it. Physics Education, 29,368- 374

Zemke, S.C., Elger, D.F.\& Beller. (2004) Tailoring Cooperative Learning Events for Engineering Classes.Proceedings, ASEC Conference and Exposition. 